\title{
TAKIKARDIA REENTRI ATRIOVENTRIKULER ORTODROMIK TERKAIT SINDROM WOLFF-PARKINSON-WHITE
}

(Laporan Kasus)

(ORTHODROMIC ATRIOVENTRICULAR REENTRANT TACHYCARDIA ASSOCIATED WITH WOLFF-PARKINSON-WHITE SYNDROME)

(Case Study))

\author{
Agustinus Vincent,${ }^{1}$ Andri Sunata ${ }^{2}$ \\ ${ }^{1}$ Dokter Umum, RSUD Kabupaten Bengkayang, Kalimantan Barat \\ ${ }^{2}$ Dokter Spesialis Penyakit Dalam, RSUD Kabupaten Bengkayang, Kalimantan Barat \\ Email korespondensi: vincentagustinus.av@gmail.com
}

\begin{abstract}
ABSTRAK
Takikardia supraventrikular (SVT) mewakili serangkaian takiaritmia yang berasal dari sirkuit atau fokus yang muncul di atas bundel His dan mengakibatkan denyut jantung melebihi $100 \mathrm{kali} /$ menit. Takikardia reentri atrioventrikuler (AVRT) ortodromik merupakan jenis SVT kedua yang paling umum dijumpai pada sekitar 55\% pasien dengan sindrom WolffParkinson-White (WPW). Sindrom WPW merupakan bentuk kelainan pre-eksitasi ventrikel yang paling umum dijumpai. Sindrom ini ditandai dengan adanya jalur aksesori antara atrium dan ventrikel yang memungkinkan adanya rute alternatif untuk depolarisasi ventrikel. Dilaporkan seorang wanita, 34 tahun dengan sindrom WPW yang terdiagnosis setelah terminasi dari takikardi kompleks sempit melalui manuver valsava yang dimodifikasi. Manuver ini merupakan teknik lini pertama yang biasa digunakan untuk mengembalikan irama sinus. Teknik non-invasif ini berfungsi untuk memperpanjang periode refrakter nodus AV melalui peningkatan tekanan intrathorakal dalam waktu singkat sehingga menstimulasi aktivitas baroreseptor di lengkung aorta dan karotis yang selanjutnya meningkatkan tonus parasimpatis. Sebagai kesimpulan, dokter perlu menyadari bahwa manuver ini berpotensi untuk menginduksi takiaritmia letal akibat blokade nodus AV sehingga memicu konduksi melalui jalur aksesori pada pasien dengan sindrom pre-eksitasi.
\end{abstract}

Kata kunci: atrioventrikuler, sindrom Wolff-Parkinson-White, takikardia 
Agustinus Vincent : Takikardia Reentri Atrioventrikuler ...

\section{ABSTRACT}

Supraventricular tachycardia (SVT) represent a range of tachyarrhythmias originating from a circuit or focus arising above the bundle of His and causing heart rates exceed 100 beats/minute. Orthodromic atrioventricular reentrant tachycardia (AVRT) is the second most common form of SVT and inducible in approximately $55 \%$ of individuals with WolffParkinson-White (WPW) syndrome. WPW syndrome is the most common form of ventricular pre-excitation. It is characterized by the presence of an accessory pathway between the atrium and ventricles which allows an alternative route for ventricular depolarization. We reported, a 34 years old female with WPW syndrome that was diagnosed following successful termination of narrow complex tachycardia after modified Valsalva maneuver. Modified Valsalva maneuver, commonly used as first-line technique to restore the normal sinus rhythm. This non-invasive technique can increase AV nodal refractoriness by increasing intrathoracic pressure for a brief period, thus stimulating baroreceptor activity in the aortic arch and carotid bodies, resulting in increased parasympathetic tone. In conclusion, clinicians need to be aware of the potential for this maneuver to induce lethal tachyarrhythmias via AV nodal blockade and preferential conduction down the accessory pathway in patients with preexcitation syndrome.

Keywords: atrioventricular, Wolff-Parkinson-White syndrome, tachycardia

\section{PENDAHULUAN}

Pada tahun 1930, Louis Wolff, Sir John Parkinson, dan Paul Dudley White menerbitkan sebuah artikel yang menggamabarkan 11 pasien yang mengalami serangan takikardia disertai dengan pola irama elektrokardiografi (EKG) blok cabang berkas dan interval PR yang pendek. Temuan ini kemudian dikenal sebagai sindrom Wolff-ParkinsonWhite (WPW), meskipun sudah ada beberapa laporan kasus yang menjelaskan temuan serupa sebelumnya. Pada tahun 1943, fitur EKG dari adanya preeksitasi dikorelasikan dengan bukti anatomi keberadaan substrat jaringan konduksi anomali sebagai rute alternatif sistem konduksi atrioventrikuler (AV). ${ }^{1}$

Mayoritas pasien yang memiliki pola WPW pada pemeriksaan EKG tidak menunjukkan gejala. Akan tetapi, populasi ini rentan terhadap serangan takiaritmia yang dapat mengancam jiwa. Sindrom WPW mungkin tetap tidak terdeteksi sampai akhirnya bermanifestasi sebagai suatu takikardia supraventrikuler (SVT), dan berkontribusi sebanyak $2,4 \%$ sebagai pasien yang datang dengan takikardia 
Agustinus Vincent : Takikardia Reentri Atrioventrikuler ...

kompleks sempit pada kunjungan di departemen emergensi. ${ }^{1}$

Takikardia supraventrikuler merupakan takiaritmia yang berasal dari sirkuit atau fokus yang muncul di atas bundel His dan mengakibatkan denyut jantung melebihi $100 \mathrm{kali} / \mathrm{menit}$. Irama yang sangat cepat ini kadang menakutkan bagi pasien terutama jika sering berulang atau persisten, dan dapat menyebabkan morbiditas yang signifikan. ${ }^{2,3}$ Takikardia supraventrikuler (SVT) (tidak termasuk atrial fibrilasi atau flutter dan takikardia atrial multifokal) diperkirakan memiliki insiden sebanyak 35 per 100.000 orang/tahun, dengan prevalensi 2.29/1000 orang. Takikardia reentri nodus atrioventrikuler (AVNRT) merupakan jenis SVT yang paling umum dijumpai pada orang dewasa (sekitar 50 hingga 60 persen), sedangkan takikardi reentri atrioventrikuler (AVRT) umumnya dijumpai pada populasi anak-anak dan pasien dengan sindrom preeksitasi (menyumbang sekiatar 30 persen dari semua SVT). ${ }^{4}$

AVRT merupakan suatu takikardia reentri yang secara anatomis terdiri dari dua jalur konduksi yang berbeda, yakni sistem konduksi AV normal dan jalur aksesori AV yang menghubungkan atrium dan ventrikel. Berbeda dengan aritmia lain yang dapat menggunakan jalur aksesori sebagai sistem konduksi dari situs anatomi asal takikardia ke daerah jantung lainnya (misalnya, atrial fibrilasi dan atrial flutter), AVRT merupakan suatu takikardia khusus dimana jalur aksesori diperlukan sebagai sistem konduksi untuk inisiasi dan keberlangsungan dari takikardia tersebut. ${ }^{5}$

Dalam laporan ini, kami akan mendeskripsikan suatu kasus tentang fitur khas sindrom preeksitasi yang terdeteksi pada pemeriksaan EKG setelah proses reversi dari suatu SVT melalui manuver valsalva yang dimodifikasi. Kami juga ingin memperingatkan tentang resiko penggunaan manuver vagal ataupun obatobatan yang dapat menghambat konduksi atrioventrikuler pada pasien-pasien dengan sindrom preeksitasi serta menegaskan kembali pentingnya pemeriksaan EKG ulang setelah manajemen dari suatu aritmia akut.

\section{LAPORAN KASUS}

Seorang perempuan, usia 34 tahun, datang ke Instalasi Gawat Darurat (IGD) RSUD Bumi Sebalo, Kabupaten Bengkayang dengan keluhan utama berupa dada berdebar sejak 30 menit sebelum masuk ke rumah sakit. Pasien juga mengeluhkan perasaan tidak nyaman di dada. Dada terasa seperti ditindih beban berat dan dirasa menembus ke belakang. Pasien juga megeluh keringat dingin, dan 
Agustinus Vincent : Takikardia Reentri Atrioventrikuler ...

sakit kepala. Pasien menyangkal keluhan sesak. Pasien mengaku sudah sering mengalami keluhan serupa sejak usia 8 tahun namun keluhan biasanya membaik dengan sendirinya dalam hitungan beberapa menit. Pasien menyangkal mengkonsumsi kafein atau obat-obatan sebelum keluhan muncul. Riwayat penyakit lain seperti hipertensi, diabetes mellitus, dan dislipidemia disangkal. Pasien tidak pernah merokok dan minum alkohol. Riwayat keluhan serupa atau kematian jantung mendadak pada keluarga juga disangkal.

Pada pemeriksaan fisik didapatkan kelainan berupa takikardia dengan diaforesis. Denyut jantung pasien kurang lebih 180 kali/menit, regular, dengan tekanan darah 110/70 mmHg. Pada pemeriksaan EKG didapatkan irama SVT dengan denyut jantung yang teratur sebanyak kurang lebih 190 kali/menit, aksis normal, dan depresi segmen ST pada sadapan I, II, III, aVF, V3-V6 (Gambar 1).

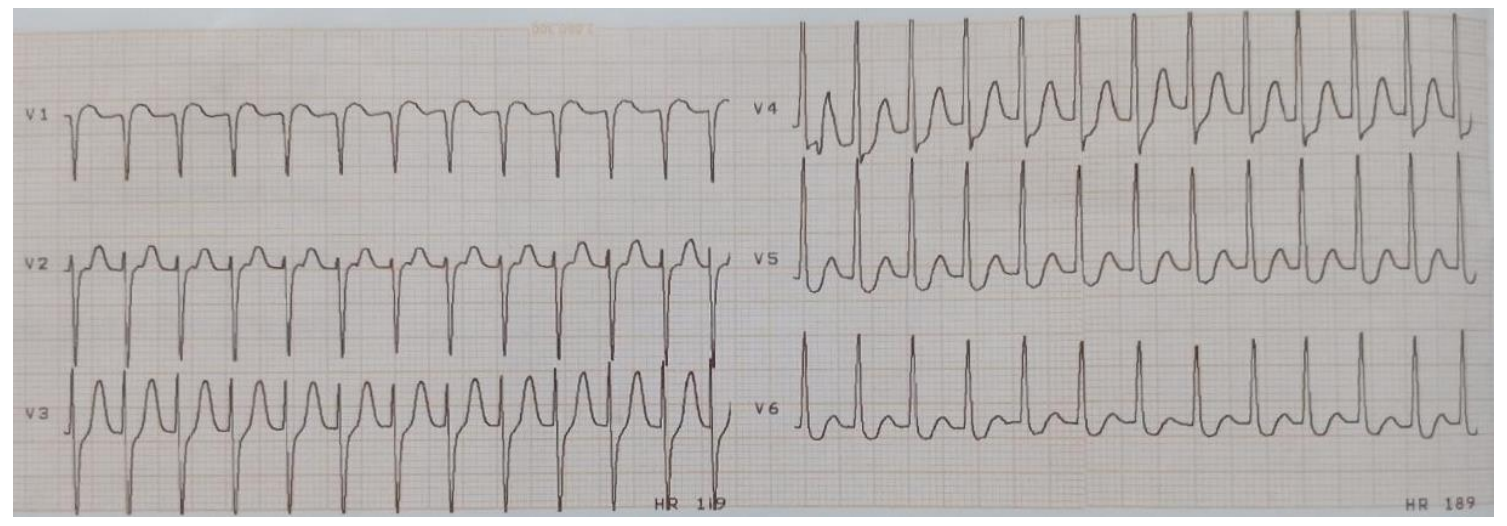

Gambar 1. Elektrokardiografi pasien yang menunjukkan irama SVT dengan denyut jantung 189kali/menit

Hasil pemeriksaan laboratorium berupa darah rutin, fungsi ginjal, fungsi hati, dan elektrolit menunjukkan hasil normal. Hemoglobin 13,8 g/dL, leukosit 9.540/uL, trombosit 217.000/uL, ureum $36 \mathrm{mg} / \mathrm{dl}$, kreatinin 0,97 mg/dL, SGOT 33 U/I, SGPT $30 \mathrm{U} / \mathrm{I}$, natrium $142 \mathrm{mmol} / \mathrm{L}$, kalium 3,7 mmol/L, klorida 100 mmol/L. 


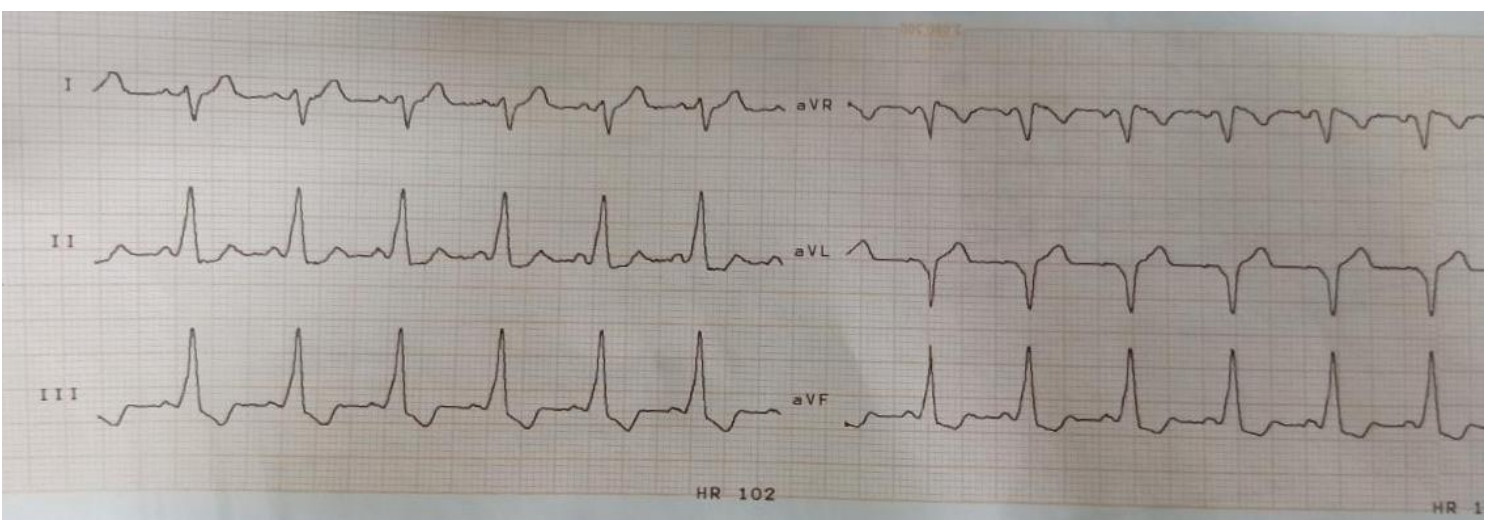

Gambar 2. Elektrokardiografi pasien menunjukkan irama sinus dengan denyut jantung 102 kali/menit dengan gelombang delta dan deviasi segmen ST yang diskordan di lead II, III, aVF, V1-V4

Pilihan terapi lini pertama untuk pasien ini adalah manuver vagal. Setelah memastikan pasien tidak memiliki riwayat penyakit serebrovaskuler dalam 3 bulan terakhir, dan tidak ditemukan adanya bruit pada kedua arteri karotis pasien. Pijat sinus karotis dilakukan pada pasien selama 5 menit tetapi tindakan ini gagal mengembalikan irama jantung pasien menjadi normal. Tindakan kemudian dilanjutkan dengan maneuver valsalva yang dimodifikasi. Status hemodinamik pasien stabil selama prosedur intervensi tanpa ditemui tanda hipoperfusi. Pada akhirnya, irama jantung pasien berhasil direversi, dan pemeriksaan EKG kembali diulang, hasil EKG menunjukkan gambaran khas dari sindrom pre-eksitasi. EKG setelah proses reversi ini menunjukkan irama sinus yang dibuktikan dengan adanya gelombang $\mathrm{P}$ dengan MK | Vol. 3 | No. 2 | APRIL 2020 defleksi positif yang diikuti oleh kompleks QRS pada sadapan II. Interval PR sangat pendek dengan gambaran gelombang delta yang khas atau gelombang bertakik yang jelas dapat diamati pada kompleks QRS di sadapan positif, terutama pada sadapan ekstrimitas. Kompleks QRS tampak sedikit melebar dengan pola blok berkas cabang kanan. Dapat juga diamati perubahan repolarisasi pada sadapan ekstremitas yang ditandai dengan deviasi segmen ST yang diskordan (Gambar 2). Seluruh temuan ini mengarahkan pasien terhadap sindrom WPW. Pasien kemudian dirawat di ICU dan diberi terapi berupa oksigenasi, pemberian cairan rumatan, dan tablet amiodarone 100mg/8jam. Pasien kemudian dirujuk ke rumah sakit rujukan Provinsi Kalimantan Barat, RSUD Dr. Soedarso, Pontianak untuk kemungkinan diperlukannya suatu studi elektrofisiologi 
Agustinus Vincent : Takikardia Reentri Atrioventrikuler ...

serta tindakan radiofrekuensi ablasi untuk mencegah berulangnya serangan aritmia atau kematian jantung mendadak.

\section{PEMBAHASAN}

Pada Tahun 1930, Louis Wolff, Sir John Parkinson, dan Paul Dudley pertama kali melaporkan 11 pasien yang menderita serangan takikardia berulang yang kemudian dihubungkan dengan temuan pola EKG khas berupa blok cabang berkas yang disertai dengan interval PR yang memendek. Temuan ini kemudian dikenal sebagai sindrom WPW. ${ }^{1}$ Sindrom WPW mungkin tetap tidak terdeteksi sampai akhirnya bermanifestasi sebagai suatu takikardia supraventrikuler (SVT) dan berkontribusi sebanyak $2,4 \%$ sebagai pasien yang datang dengan takikardia kompleks sempit pada kunjungan di departemen emergensi. ${ }^{1}$

SVT merupakan suatu penyakit yang sering dijumpai. Data dari United States (US) menunjukkan bahwa SVT berkontribusi terhadap 50.000 kunjungan departemen emergensi setiap tahunnya. Di US, prevalensi dari SVT paroksismal pada populasi umum adalah sebanyak 2.25 per 1000 populasi dengan insiden sebanyak 35 per 100.000 orang/tahun. ${ }^{6}$

SVT mewakili serangkaian takiaritmia yang berasal dari sirkuit atau fokus yang melibatkan atrium dan nodus atrioventrikuler. Istilah SVT paroksismal selanjutnya mewakili kejadian SVT yang muncul sebagai suatu sindrom klinis yang ditandai dengan takikardia regular dengan onset mendadak yang dapat mengalami terminasi dengan sendirinya. SVT biasanya merupakan suatu takikardia kompleks sempit dengan interval QRS kurang dari $100 \mathrm{~ms}$ pada pemeriksaan EKG. Pada kondisi khusus, SVT dapat menunjukkan gambaran kompleks QRS yang lebar apabila terdapat suatu aberansi karena suatu hambatan konduksi atau pada blok cabang berkas. Pemahaman serta identifikasi dini dari irama ini sangatlah penting untuk menentukan manajemen yang tepat pada kondisi akut, termasuk mengidentifikasi pasien yang memerlukan terapi definitif dengan ablasi kateter. ${ }^{3}$

Dalam suatu studi retorespektif tunggal yang melibatkan 1754 pasien yang menjalani prosedur ablasi kateter untuk SVT paroksismal, mekanisme yang paling umum dijumpai pada populasi laki-laki adalah AVRT, sedangkan untuk AVNRT dan takikardia atrial lebih umum dijumpai pada populasi wanita. Pada kedua populasi ini, proporsi pasien AVRT menurun seiring bertambahnya usia sedangkan proporsi AVNRT meningkat seiring dengan pertambahan usia. Secara keseluruhan, mekanisme SVT yang paling 
Agustinus Vincent : Takikardia Reentri Atrioventrikuler ...

umum dijumpai adalah AVNRT diikuti oleh AVRT dan takikardia atrial. ${ }^{4}$

AVRT merupakan suatu takikardia reentri yang terjadi pada pasien-pasien dengan sindrom WPW. Pada AVRT, nodus atrioventrikuler dan jalur aksesori berperan dalam membentuk suatu sirkuit antara atrium dan ventrikel yang memungkinkan adanya proses reentri dari impuls yang dihasilkan. Ada dua bentuk AVRT: ortodromik, dan antidromik. Pada AVRT ortodromik, impuls dari atrium dikonduksikan ke ventrikel melalui nodus atrioventrikuler, kemudian dikonduksikan kembali secara retrograd melalui jalur aksesori yang memungkinkan impuls tersebut masuk kembali ke dalam sistem konduksi sehingga takikardia terjadi secara terus-menerus. $^{7}$

AVRT ortodromik menyumbang 9095\% kasus dari keseluruhan takikardia reentri yang terjadi pada pasien dengan sindrom WPW, aritmia ini biasa dicetuskan oleh suatu denyut ekstrasistol atrium atau ventrikel. ${ }^{7,8}$ Gambaran EKG pada AVRT ortodromik, biasanya menunjukkan suatu irama teratur dengan kecepatan ventrikel yang berkisar dari 150 hingga 250 denyut/menit. Gelombang $\mathrm{P}$ defleksi negatif dengan interval PR yang memendek juga dapat diamati. Depresi segmen ST juga dapat ditemukan pada AVRT ortodromik, perubahan pada tonus sistem saraf otonom, gangguan konduksi intraventrikuler, interval atrioventrikuler yang memanjang, dan gelombang $\mathrm{P}$ retrograd yang tumpang tindih dengan segmen ST berkontribusi terhadap gambaran depresi segmen ST. ${ }^{9}$

Meskipun temuan klasik untuk menegakkan diagnosis sindrom WPW adalah ditemukannya interval PR yang pendek dan gelombang delta dengan kompleks QRS yang lebar, disritmia yang paling umum terjadi adalah takikardia kompleks sempit. Secara umum, sulit untuk membedakan SVT paroksismal yang diakibatkan oleh AVNRT dengan SVT paroksismal yang diakibatkan oleh AVRT ortodromik karena keduanya akan menghasilkan gambaran takikardia kompleks sempit pada pemeriksaan EKG. ${ }^{9}$

Tanda khas yang dapat ditemui apabila SVT paroksismal diakibatkan oleh suatu AVRT ortodromik, yaitu depresi segmen ST, dan adanya osilasi antar denyut pada amplitudo QRS. Sebuah aspek yang dapat diamati pada EKG untuk menentukan diagnosis diferensial adalah pada AVNRT, gelombang $\mathrm{P}$ dapat diamati pada kompleks QRS atau di akhir kompleks QRS, namun pada SVT yang dimediasi oleh suatu jalur aksesori, gelombang $\mathrm{P}$ dapat diamati setelah kompleks QRS karena impuls harus berjalan terlebih dahulu di ventrikel dan jalur aksesori sampai akhirnya sampai 
Agustinus Vincent : Takikardia Reentri Atrioventrikuler ...

di atrium. Ketika irama jantung telah kembali normal, interval PR yang pendek, dan gelombang delta selanjutnya dapat diamati.

Saat melakukan penilaian pada pasien dengan kecurigaan SVT, penting untuk mengevaluasi status hemodinamik pasien dengan cepat. SVT jarang berakibat fatal tetapi resiko kematian jantung mendadak tahunan, kasus ini mencapai 0,02\%-0,15\% pada pasien-pasien dengan sindrom WPW. ${ }^{3}$ Meskipun demikian, pada pasienpasien tertentu dengan komorbiditas jantung mungkin tidak dapat mentolerir laju ventrikel yang terlalu cepat, yang selanjutnya dapat mengakibatkan ketidakstabilan hemodinamik, eksaserbasi gagal jantung kongestif, atau angina. Apabila pasien dianggap tidak stabil akibat SVT, dan percobaan manuver vagal maupun pemberian adenosine intravena tidak efektif atau tidak tersedia, kardioversi listrik tersinkronasi harus segera dilakukan pada pasien-pasien tersebut. ${ }^{3}$

Pada pasien dengan SVT, EKG 12sadapan berfungsi untuk mengidentifikasi mekanisme aritmia yang terjadi (Gambar3). Takikardia tersebut pertamatama harus diklasifikasikan berdasarkan teratur atau tidaknya laju ventrikel. Laju ventrikel yang tidak teratur mengindikasikan suatu atrial fibrilasi (AF), takikardi atrial multifokal (MAT), atau flutter atrium dengan konduksi AV yang bervariasi. Perhatian lebih harus ditekankan pada kasus AF dengan respon ventrikuler cepat, ketidakteraturan dari respon ventrikel terkadang sulit untuk dideteksi dan bisa salah didagnosis sebagai suatu SVT. ${ }^{3}$

Apabila ditemukan SVT yang reguler, temuan ini dapat mewakili AT dengan konduksi 1:1 atau SVT yang melibatkan nodus AV. Suatu takikardia junctional, yang berasal dari simpang AV (termasuk bundle His), bisa regular atau ireguler, dengan konduksi yang bervariasi ke atrium. SVT yang melibatkan nodus AV sebagai komponen yang diperlukan dalam sirkuit takikardia reentri mencakup AVNRT, dan AVRT. Dalam takikardi reentri ini, gelombang $\mathrm{P}$ yang dikonduksikan secara retrograd sulit untuk dapat diamati, terutama jika ada suatu blok cabang berkas. Pada AVNRT tipikal, aktivasi atrium hampir terjadi bersamaan dengan QRS, sehingga bagian akhir dari gelombang $\mathrm{P}$ biasanya terletak di ujung kompleks QRS, muncul sebagai gelombang $\mathrm{P}$ yang sempit dengan defleksi negatif pada sadapan inferior (gelombang pseudo S) dan defleksi positif pada akhir kompleks QRS pada sadapan V1 (pseudo R'). Pada AVRT ortodromik (dengan konduksi anterograd melalui nodus AV), gelombang $\mathrm{P}$ biasanya dapat dilihat pada 
Agustinus Vincent : Takikardia Reentri Atrioventrikuler ...

bagian awal segmen ST-T. Dalam bentuk AVNRT dan AVRT yang tipikal karena gelombang $\mathrm{P}$ terletak dekat dengan kompleks QRS sebelum dan sesudahnya. Takikardi ini sering disebut takikardi dengan segmen PR yang pendek yang memiliki hubungan 1:1 antara gelombang P dan kompleks QRS, kecuali pada beberapa kasus AVNRT langka dimana dapat terjadi blok AV 2:1 atau AV blok lainnya dengan berbagai derajat blok. Pada beberapa kasus AVNRT yang tidak biasa (seperti pada cepat-lambat), gelombang $\mathrm{P}$ terletak lebih dekat ke kompleks QRS berikutnya. Interval PR yang panjang dapat ditemui pada kasus AVRT yang tidak biasa, dikenal sebagai takikardi reentri junctional permanen (PJRT), yang terdapat jalur aksesori tidak biasa yang bertindak sebagai jalur pintas untuk konduksi retrograd yang lambat dari AVRT ortodromik sehingga menghasilkan penundaan aktivasi atrium dan menghasilkan interval PR yang panjang. ${ }^{3}$

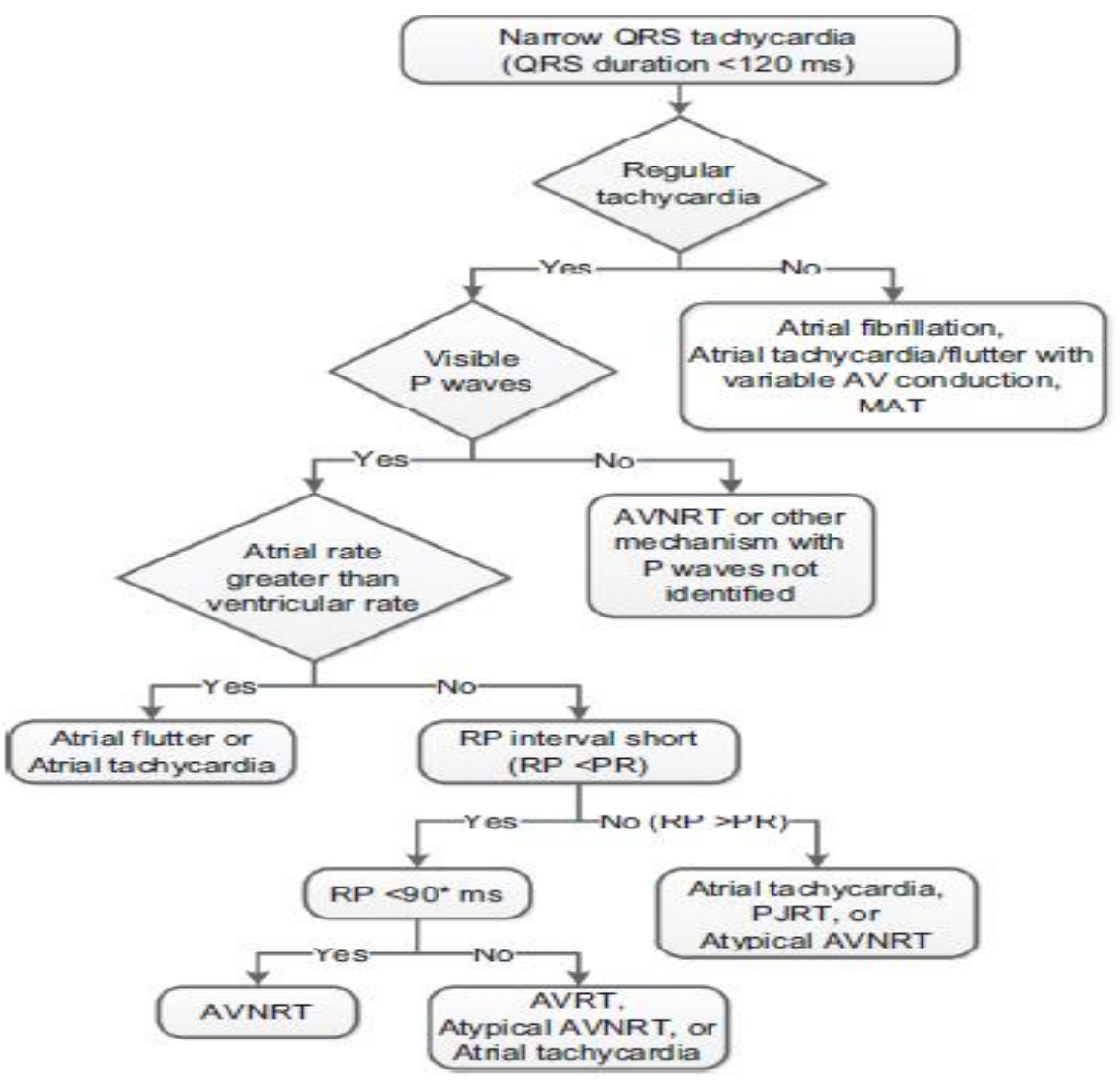

Gambar 3. Alogaritme diagnosis banding untuk suatu takikardia kompleks sempit pada pasien dewasa. AV, atrioventrikuler; AVNRT, takikardi reentri nodus atrioventrikuler; AVRT, takikardi reentri atrioventrikuler; ECG, elektrokardiografi; MAT, takikardi atrial multifocal; dan PJRT, takikardi reentri junctional permanen. ${ }^{3}$ 
Agustinus Vincent : Takikardia Reentri Atrioventrikuler ...

Interval PR yang panjang merupakan temuan khas yang dapat ditemui pada AT karena irama ini dicetuskan oleh atrium dan mengikuti jalur konduksi normal ke ventrikel. Pada AT, EKG biasa akan menunjukkan gelombang $\mathrm{P}$ dengan morfologi yang berbeda dari sinus, gelombang $\mathrm{P}$ ini dapat diamati pada akhir kompleks QRS atau segera setelah gelombang T. pada takiakardi reentri yang melewati nodus sinus, suatu bentuk AT yang fokal, morfologi gelombang $\mathrm{P}$ bisa identik dengan gelombang $\mathrm{P}$ pada irama sinus. $^{3}$

Pada pasien SVT dengan status hemodinamik yang stabil, begitu hasil EKG diperoleh, uji coba manuver vagal direkomendasikan untuk dilakukan dibawah pemantauan EKG. ${ }^{3}$ Pada pasien dengan AVRT atau AVNRT, manuver vagal dapat memutus sirkuit reentri dan mengembalikan irama sinus. Baik pijat sinus karotis dan manuver valsalva dapat meningkatkan tonus saraf vagus. Sebelum melakukan pijat sinus karotis, auskultasi untuk identifikasi bruit arteri karotis harus dilakukan untuk menghindari kompresi pada plak aterosklerotik yang dapat memicu suatu kejadian emboli. Apabila tidak terdengar adanya bruit, pasien selanjutnya diminta untuk mengahadap sisi yang berlawanan dari arteri karotis yang akan dipijat. Dengan menggunakan dua jari, lakukanlah kompresi pada arteri karotis sejajar dengan sudut rahang. Manuver ini harus dilakukan pada kedua sisi arteri karotis karena beberapa pasien terkadang merespon lebih baik pada salah satu sisi dibanding dengan sisi lainnya. Kedua arteri karotis tidak boleh dikompresi dalam waktu bersamaan. Kontraindikasi dari pijat sinus karotis adalah bruit pada arteri karotis, takiaritmia ventrikuler, dan riwayat stroke atau infark miokard dalam tiga bulan terakhir. ${ }^{10}$

Manuver Valsalva pertama kali diterbitkan oleh Antonio Maria Valsalva pada tahun 1704 dalam karyanya yang berjudul De Aura Humana Tractatus, yang didefinisikan sebagai suatu prosedur untuk mengeluarkan eksudat nanah dari telinga tengah seorang pasien. Prosedur ini selanjutnya terus berkembang dan dapat beradaptasi dengan relevansi kebutuhan perkembangan dunia kedokteran di berbagai disiplin ilmu. Meskipun tidak diketahui dengan pasti mengenai kapan manuver ini pertama kali diterapkan untuk terminasi SVT (baik dalam bentuk AVRT atau AVNRT) pada pasien dengan hemodinamik stabil, namun hal ini diperkirakan bertepatan dengan munculnya elektrokardiografi. Manuver Valsalva mencakup 3 elemen spesifik yang harus dipenuhi untuk menghasilkan efek yang maksimal, yakni: 
a. Postur pasien (terlentang),

b. Manuver untuk menghasilkan tekanan intratorakal $(40 \mathrm{mmHg})$,

c. Mempertahankan durasi strain (15 detik).

Apabila seluruh prosedur elemen ini dipenuhi, manuver ini dapat menghasilkan respon parasimpatis (vagal) yang maksimal dan dapat mereversi aritmia pasien. Pada tahun 1936, Hamilton menjelaskan bahwa manuver Valsalva terdiri dari 4 fase utama, yakni:

- Fase 1. Pada fase ini terjadi peningkatan tekanan intratorakal dalam waktu singkat, sehingga menstimulasi aktivitas baroreseptor di lengkung aorta dan karotis yang selanjutnya meningkatkan tonus parasimpatis dan mengurangi laju denyut jantung. Tekanan yang dihasilkan pada fase ini diakibatkan oleh efek kompresi dari tekanan intratorakal pada aorta torakalis.

- Fase 2. Periode ini ditandai dengan berakhirnya peningkatan intratorakal yang selanjutnya mengakibatkan penurunan tekanan pada aorta dan meningkatnya denyut jantung.

- Fase 3. Fase ini terjadi pada akhir periode strain dari manuver Valsalva yang selanjutnya juga mengakibatkan penurunan tekanan aorta dalam waktu singkat dan juga berkontribusi terhadap peningkatan denyut jantung pasien.

- Fase 4. Fase ini terjadi sebagai akibat peningkatan aliran vena balik dan peningkatan volume preload jantung yang selanjutnya meningkatkan tekanan aorta, dan curah jantung, tubuh selanjutnya akan melakukan kompensasi untuk menurunkan denyut jantung pasien.

Pada pasien dengan status hemodinamik stabil seperti pada kasus ini, pijat sinus karotis merupakan terapi lini pertama karena tindakan ini dapat memutus sirkuit AVRT dan mengembalikan irama sinus. Setelah upaya percobaan pijat sinus karotis selama 5 menit, AVRT masih tetap berlangsung. Berdasarkan sebuah studi kasus prospektif acak berskala kecil, konversi terjadi hanya pada $9(10,5 \%)$ dari 86 pasien dengan SVT yang menerima pijat sinus karotis. Pasien kemudian dipersiapkan untuk dilakukan maneuver Valsalva termodifikasi yang pada akhirnya berhasil mereversi irama jantung pasien. Sebuah ulasan dari Cochrane menjelaskan tingkat keberhasilan reversi dari manuver Valsalva yang bervariasi antara 19,4\% hingga 54,3\%. ${ }^{11} \quad$ Appelboam, dkk. membandingkan manuver Valsalva standar dengan manuver Valsalva termodifikasi 
Agustinus Vincent : Takikardia Reentri Atrioventrikuler ...

yang mencakup manuver Valsalva yang sama-sama dilakukan dalam posisi semitelentang namun segera setelah pasien meniup syringe, pasien kemudian diarahkan untuk berbaring sambil menaikkan kakinya sebesar $45^{\circ}$ selama 15 detik. Manuver Valsalva termodifikasi terbukti lebih efektif dalam terminasi irama SVT dibanding dengan manuver Valsalva standar $(43 \%$ v. $17 \%){ }^{12}$

Kasus ini merupakan sebuah kasus tipikal SVT yang berhasil dikelola dengan manuver Valsalva termodifikasi dimana setelahnya, gelombang delta dapat diamati pada EKG yang mengindikasikan adanya suatu pre-eksitasi pada sindrom WPW. Pada kasus ini, tidak ada kepentingan secara klinis bagi kita untuk membedakan apakah SVT yang terjadi mengikuti mekanisme AVNRT atau AVRT karena keduanya dapat diterapi dengan manuver atau obat-obatan yang dapat menghambat nodus AV. Akan tetapi, penting bagi kita untuk mengamati bahwa pada kasus-kasus tertentu dimana pasien memiliki sindrom pre-eksitasi, manuver vagal berpotensi memicu potensi AF yang telah ada sebelumnya, kejadian ini selanjutnya dapat berakibat fatal apabila laju ventrikel terlalu cepat. Tingginya insiden atrial fibrilasi pada pasien dengan jalur aksesori dibandingkan dengan pasien-pasien dengan AVNRT disebabkan oleh penurunan periode refrakter atrium akibat manuver vagal dan aktivasi impuls listrik pada substrat anatomis AVRT akibat arborisasi yang terjadi pada jalur aksesori. ${ }^{9}$

Pada pasien AF terkait sindrom WPW yang tidak stabil harus segera mendapat terapi kardioversi tersinkronisasi. Obatobatan yang dapat menghambat nodus AV harus senantiasa dihindari penggunaannya pada semua kondisi. Agen-agen ini termasuk agen penghambat beta, agen penghambat kanal kalsium, adenosine, dan digoksin. Agen tersebut dapat meningkatkan konduksi melalui jalur aksesori yang menghasilkan konduksi preferensial pada jalur aksesori yang selanjutnya akan mempercepat laju ventrikel, dan mengakibatkan kolaps kardiovaskuler. ${ }^{13}$ Adenosine merupakan agen yang banyak digunakan sebagai lini pertama manajemen akut, secara umum dianggap aman dan efektif sebagai agen diagnostic, dan terapeutik. Efek samping yang umum terjadi pada penggunaan adenosine adalah bronkospasme, nyeri dada, bradikardia, dan takiaritmia letal terutama pada pasien dengan pre-eksitasi. Oleh karena itu, mengingat takiaritmia yang dapat terjadi berpotensi letal, pemberian adenosine ataupun manuver vagal hanya boleh dilakukan apabila defibrilasi dan obat antiaritmia tersedia dan dapat diakses dengan cepat. 


\section{KESIMPULAN}

SVT merupakan kasus takiaritmia yang sering dijumpai di departemen emergensi setiap tahunnya. SVT mewakili mewakili serangkaian takiaritmia yang berasal dari sirkuit atau fokus yang melibatkan atrium dan nodus atrioventrikuler. Secara keseluruhan, mekanisme SVT yang paling umum dijumpai adalah AVNRT diikuti oleh AVRT dan takikardia atrial. AVRT merupakan suatu takikardia reentri yang terjadi pada pasien-pasien dengan sindrom WPW. Ketika seluruh riwayat pasien dan status hemodinamik pasien telah dievaluasi, manuver vagal tetap menjadi agen lini pertama pada takikardia kompleks sempit yang reguler, namun perlu untuk selalu diingat bahwa manuver ini berpotensi memicu kolaps kardiovaskular pada kasus-kasus tertentu. Kasus ini juga menekankan pentingnya menilai kembali EKG dan kondisi pasien setelah manajemen suatu SVT.

\section{DAFTAR PUSTAKA}

1. Wolff L, Parkinson J, White PD. Bundle-branch block with short P$\mathrm{R}$ interval in healthy young people prone to paroxysmal tachycardia. 1930. Ann Noninvasive Electrocardiol. 2006; 11:340.

2. Fuster V, Rydén LE, Cannom DS, et al. ACC/AHA/ESC 2007 guidelines for the management of patients with atrial fibrillation: a report of the American College of Cardiology/American Heart Association Task Force on Practice Guidelines and the European Society of Cardiology Committee for Practice Guidelines (writing committee to revise the 2001 guidelines for the management of patients with atrial fibrillation): developed in collaboration with the European Heart Rhythm Association and Heart Rhythm Society [published correction appears in Circulation. 2007;116(6):e138]. Circulation. 2006;114(7):e257e354.

3. Page RL, Joglar JA, Caldwell MA, Calkins H, Conti JB, Deal BJ, Estes NAM 3rd, Field ME, Goldberger ZD, Hammill SC, Indik JH, Lindsay BD, Olshansky B, Russo AM, Shen W-K, Tracy CM, AlKhatib SM. 2015 ACC/AHA/HRS guideline for the management of adult patients with supraventricular tachycardia: a report of the American College of Cardiology/American Heart Association Task Force on Clinical Practice Guidelines and the Heart 
Rhythm Society. Heart Rhythm 2016;13;e136-e221

4. Porter MJ, Morton JB, Denman R, et al. Influence of age and gender on the mechanism of supraventricular tachycardia. Heart Rhythm. 2004;1(4):393-396.

5. Josephson ME. Preexcitation syndromes. In: Clinical cardiac electrophysiology, 4th, Lippincot Williams \& Wilkins, Philadelphia .2008. p.339

6. Murman DH, McDonald AJ, Pelletier AJ, et al. U.S. emergency department visits for supraventricular tachycardia, 19932003. Acad Emerg Med 2007; 14:578-81.

7. Josephson ME. Preexcitation syndromes. In: Clinical cardiac electrophysiology, 4th, Lippincot Williams \& Wilkins, Philadelphia 2008. p. 339.

8. Chugh A, Morady F. Atrioventricular reentry and variants. In: Cardiac electrophysiology from cell to bedside, 5th edition, Zipes DP, Jalife J. (Eds), Saunders/Elsevier, Philadelphia 2009;p. 605-614.

9. Yong CC, Jian GA. A Case of supraventricular tachycardia associated with Wolff-ParkinsonWhite Syndrome. J Med Cases. 2018;9(2):54-57

10. Mann DL, Zipes DP, Libby P, et al., editors. Braunwald's heart disease: a textbook of cardiovascular medicine. 10th ed. Philadelphia: Saunders; 2014.

11. Smith GD, Fry MM, Taylor D, et al. Effectiveness of the Valsalva Maneuvre for reversion of supraventricular tachycardia. Cochrane Database Syst Rev 2015;(2):CD009502.

12. Appelboam A, Reuben A, Mann C, et al. Postural modification to the standard Valsalva manoeuvre for emergency treatment of supraventricular tachycardias (REVERT): a randomised controlled trial. Lancet 2015;386:1747-53.

13. Camm AJ, Kirchhof P, Lip GY, Schotten U, Savelieva I, Ernst S, Van Gelder IC, et al. Guidelines for the management of atrial fibrillation: The Task Force for the Management of Atrial Fibrillation of the European Society of Cardiology (ESC). Europace. 2010;12(10):1360-1420. 